\title{
Customer Relationship Management (CRM) - In Modern Banking
}

\author{
Sharmiladevi Parthiban ${ }^{1}$, Sakthi Priya E. ${ }^{2}$ \\ ${ }^{1}$ Lecturer, International Training Institute, Port Moresby, Papua New Guinea \\ ${ }^{2}$ Ph.D. Research Scholar, Bharathiar University Arts and Science College, Gudalur, Tamil Nadu, India
}

\begin{abstract}
In Today's scenario, companies quest for customers to please them in every respect and offer them the best deal." Customer is everything "is the new realization of every profit - making company because they are the revenue and profits. It is also significant to note that if customers bring in profits for the company, it becomes domineering for the company to provide excellent services otherwise they may switch to other companies. Among this some Indian banks and PSBs (private sector banks) were driven for a long period by the fulfillment of service objectives. This paper highlights from the perspective of profitability, Implementation process that adopted currently and benefited from it. It also focuses on how the banks are rendering services to attract and retain their customers; this can be analyzed on following Parameters such as Product, People, Service and Images. Some of the measures are also suggested to maintain CRM practices in banks. In the customer profit Paradigm it is very important to note how customers vary in greater degree in terms of their purchasing power and income. Some banks and financial institutions undertaken a thorough research and apply the results beneficially how CRM is accepted as the current Marketing Strategy and put into Practice properly. In today's growing competition, dynamic marketplaces, changing global marketing strategies CRM become extremely difficult for the organization to stay ahead of their competition. The life time value of the customers is turning towards implementing CRM in their organizations. To succeed, Banks should understand the needs of the customers and their perception is the basis of CRM. Banking sectors had failed to respond to changing market realities of CRM have historically been hurdle to the development of financial sector in many developing economies.
\end{abstract}

Keywords: Customer Relationship Management, Banking, Multi Domain Skill, Boundary Spanning Skill, Strategy, and Competence

\section{Introduction}

In the rapidly changing global and technological environment there has been a growing interest among financial institution as well as other types of businesses to cultivate customer relationship. The focus of banking is also undergoing a change not only in private banks but also in commercial banks and co-operative banking segments. In recent years there has been a growing interest among financial institutions, as well as other types of businesses, to cultivate customer relationships. While many companies are eager to build relationships with their customers, not all customers require themselves as having a relationships with the companies with whom they do business. From Henley research Centre they found that from academic stand point it is easy to understand the customers interest to develop a relationship in banks and financial services context. The services rendered by the banks are intangible and therefore, often difficult to understand. Before Technology revolutionized many customers could make contact with their banks thru network or door- door sales representatives; both relying on the personal contact.

The rapid transformation during the last decade in the Indian banking industry has indeed made it stronger, cleaner, efficient, disciplined, responsive to customer needs and a lot more competitive. Nowadays Indian Banking industry started comparing itself reasonably well with the rest of Asia in some areas like profitability, service, growth and low- rate of non-performing assets, innovations, customer value creations etc. Cost of intermediation in Indian Banks is still comparatively high because of factors such as higher customer relationship. Banking sector that had failed to respond to changing market realities have historically been hurdle to the development of financial sector in many developing nations.

\section{An Overview of CRM Practices in Banks}

Innovative strategies for distributing and delivering services ensure a better competitive advantage. Some of the note worthy ones, banks until a decade ago, was brisk and mortar institutions that usually allow the customer to conduct their banking needs between $10 \mathrm{am}$ and 2 p.m. but now philanthropy of initiative have transformed the distribution and delivery of banking services. Banks like ICICI extended their banking transactions from 8 am to $8 \mathrm{p}$.m. the mode of transaction are i) Internet ii) Telephone iii) ATM iv) Call bank's representative home. The note worthy is that by enabling customers more convenience the banks has not only won the heart of customers, but also technology enabled automated systems (like ATM's Internet) have resulted in lesser Transaction cost of Banks. Some Indian banks and PSBs (public sector banks) were driven for a long period by the fulfillment of services objectives. This paper highlights how Banks are implementing various processes for the benefit of customers. It also focuses on how banks render their service to attract and retain their customers. The current practices of Indian banking industries vary in terms of purchasing power and income. Due to this some banks and financial institutions undertake a thorough research and apply their results beneficially how CRM is accepted as the current marketing strategy and put into practice properly. The life time values of customers are turning towards implementing the CRM in their Banks.

Customer information is used to identify and select target markets and to position the product or service suitably. There are 4 components that determine the perceived value 


\section{International Journal of Science and Research (IJSR) \\ ISSN (Online): 2319-7064 \\ Index Copernicus Value (2013): 6.14 | Impact Factor (2015): 6.391}

of the customers such as benefits of the products and services is compared with competitions. Performance benefits as perceived by the customer and relative importance of each of these benefits to the customer are measured under some circumstances.

Some of the approaches adopted by the banks to evaluate the perceived value of the customers are:

1) Value - in use: The value of the customers can be evaluated based on the current product and service. This estimates the economic impact of the customers.

2) Direct customer response: Banks estimates how the customers react when their expectations are not fulfilled.

3) Indirect customer response: Here many banks are doing marketing research to estimate perceived value for their products or services.

4) Subjective estimation: If statistical techniques are not feasible the approach which can be adopted is the subjective approach.

Banks follows three important steps in improving customer relationships are of:

1) To identify the "most valuable customer segments in the market - To generate ROI on customer relationship management and to maintain sustainable competitive advantage in the long run.

2) To identify "The key drivers "of customer relationships which practices towards the right track of maximizing ROI.

3) Monitoring Customer relationship: Banks cannot achieve optimal customer relationship within short duration because competition is keep changing this helps the banks to trace out the performance of CRM.

\section{Measures undertaken by the banks to maintain CRM:}

The satisfied customers are central to optimal performance and financial returns customers are in groups whose satisfaction must be incorporated in strategic planning efforts. Banks can determine the actions to meet the customer needs and they follow CRM measurement to promote and stimulate improvements in the working environment. In such situation the bankers has to work hard to capitalize on the emotional aspect of their customers to feel comfortable and at ease and not intimidated. To influence the customer emotionally; the bankers has to focus on the following basics.

1) Customers are the real employer: Real customers may become pigments of the collective imagination it means the undifferentiated mass in selling to a lowest common denominator at the lowest possible price. It means the banks tie-up their serving with internal customers.

2) 4 C's of customer focused solutions: Many successful banks looking to grow in commoditized market place to offer a better customer solutions and it may also bring significant changes in all the area to deliver the real solutions to develop CRM. The 4 C's are Co-ordination, co-operation, capability and Connection.

a) Co-ordination: Is to deliver customer focused solution banks need to adopt a mechanism of customer - related information sharing, attending queries and involving them in decision - making.
b)Co-operation: Here the banks develop Metrics to measure the customer satisfaction and incentives that reward the cost focused on behaviors should get the authority to act on their behalf.

c) Capability: When the banks delivering cost focused solutions it required at least some customers to have 2 kinds of generalist skill. They are multi domain skill and boundary spanning skill i.e. the experience with service along with deep knowledge of customers need is called Multi domain skill.

d)Ability to transverse internal boundaries i.e. they should have the knowledge of investment and should set clear path it is known as boundary spanning skill. This should be developed to eradicate conflicts in the minds of the customers.

e) Connection: Many banks work together based on mergers and acquisitions in order to connect and resolve the perceived conflicts arise to customers and to look after the core activities.

3) Offer contractual Safeguards: The safeguards such as guarantees, warranties and other explicit promises need to trust the behavior of the customers to maintain their relationships, for example, the value of an investment in $\mathrm{X}$ Years' time are not common as such outcomes are determined by the factors such as service, distribution etc., whenever the inconsistency arises customers should feel that they would be compensated or will be made aware of coercive action.

4) Build customer Confidence: An act of trust occurs when the customers has confidence that the banks will honor its promises. Confidence can be derived from various sources like previous satisfying experience will reduces the risk and increases trust. Recommendation based experiences 'word of mouth, good publicity, and advertising from credible sources can increase the relationship between banks and customers.

5) Emphasize Competence: Competence is ability to provide quality products and services and to offer technical knowledge from its bank staffs. Not only that understanding the customer's requirements and able to meet out accordingly. The banks should check the records of customers are accurate; databases are updated on various transactions. Thus the customers evaluate the banks standards and competency.

6) Communication: It is an exchange of information which builds strong trust and relation. Communication means developing a shared understanding of relationship and is achieved by keeping an open dialogue with customers, hearing complaints and acting on them, keeping customers informed of changes will retain the relationship forever.

7) Commitment to the customer: It can be exhibited in number of ways like adjusting products to meet the requirements of the customers or by investing in the relationship. Commitment clearly shows customers that they are being put first and is a key manifestation of a product-orientation.

8) Perceived Conflicts: The conflict is inherent in banks services -customer relationship. The issue, however, is how the institutions deal with conflicts as they arise. Some anticipated conflicts may be protected by safeguards. Many banks encourage their customers to make use of their contacts to develop their relations. 


\section{International Journal of Science and Research (IJSR) \\ ISSN (Online): 2319-7064 \\ Index Copernicus Value (2013): 6.14 | Impact Factor (2015): 6.391}

Perceived conflicts can be reduced by improving both quantity and quality of information. It can results in customers who are aware and better educated by way of advice to handle the situation ease.

9) CRM Strategy: Many banks and financial companies build customer care culture in their internal customers, so this customer care becomes part of their integral functional process. Today customers are demanding and knowledgeable. So instead of trying to maximize profit from each transaction the banks can focus to maximize the lifetime value of the customers. Some banks like ICICI, HDFC, UTI, HSBC etc. adopted CRM strategy to build long term relationship. Here are six steps followed by banks:

a) Keep updating the customer profile.

b) Approach them with a mix of innovative products/service, customer care and growth opportunities.

c) Cover them by educating IT architecture to feed their aspirations.

d) Boldly choose the target customers for the first wave of CRM.

e) Rank or cluster them in accordance of costs, revenue, profit potential and relationship intention.

f) Calculate the lifecycle value of your customers.

10) Reshaping the delivery Mechanism: With dramatic transformation of the banking sector; banks will have to be more careful while they reshape their product profile to attract more customers. New products will have to be more customers - oriented -many of them are demanding complex banking solutions to their problems of investments and fund transfers under the same roof. Banks have an opportunity to develop products with the help of modern technology and offering technology based services. Indian banking system is also gearing up to serve better for rural peoples the Self-help groups (SHG's) in the big way in the coming years. CRM can be improved by structuring the rural credit delivery system for social purposes will have to be redesigned to cater the multiple needs of self help groups both in rural and urban areas.

11) Effectiveness of CRM: The essence of CRM in banking is to offer the right product at the right time through a proper delivery channel. The major challenges of banks are what drive the growth of CRM at Banks? According to experts the first and dominant reason is to increase consumerism.

- Firstly, people have forgotten into the habit of spending a bid to better life style.

- Secondly, the reason for the phenomenal growth was using of debit cards and credit cards in past 3 years is the intensifying competition.

- Banks are installing increasing numbers of point of sale (POS) terminals (electronic data capture swipe machine for accepting debit and credit Payments) which makes customer easier.

- Banks are managing customer relationships by improving compliant management initiatives i.e.; by giving Toll free customer care numbers makes them to clarify their queries.

Banks retain their customers by offering personalized services through single window system approach. They have to open more opportunities to offer cross selling of facilities.
Many banks are already working on it, but still they have to go a long way.

Banks are also categorizing their customers in various segments like personal finance, business finance and corporate partly in order to implement more pragmatic CRM system. Some banks are also developing universal banking systems and converting themselves into financial supermarkets capable of dispensing various services including insurance. Banks like SBI, HDFC, ICICI, and CANARA bank. All this banks transformed themselves into this system with greater focus on the delivery of products and services.

Even UTI planned to concentrate on its rural expansion, delivery system to customers along the supply chain and diversify into wider financial arena. In order to increase the customer satisfaction and customer relationship they have plans to foray into insurance and may launch a brokerage arm and positive custodial service.

\section{Conclusion}

The above insights into Banks' management of customer relationships show that CRM has been one of the powerful areas of management focus in financial industry. Banks are adopting this across the globe. The focus on CRM has been increased in the past decade and the forecast for the future is similar many banks trying to adopt this strategy. CRM implementation supports many banks to maintain relationships and serving their customers better, banks can retain their customers, by basically providing unforgettable experiences of its services. IDC Company conducted a survey on banks and financial institutions and revealed the findings which showed eight Asian financial companies which have implemented CRM practices showed good results. These eight companies are Bank of Philippine Islands, Chain trust commercial bank (Taiwan), DBS Bank (Singapore), HDFC Bank (India), HSBC Hong Kong, ICICI Bank (India) OCBC Bank (Singapore) and united Overseas Bank (Singapore). An interesting point to be noted is that two Banks are Indian Banks which has accomplished good outcome. Eventually these are the tools available to maintaining emotional attachments like friendliness or being empathetic will play a great role in CRM Implementation. The banking sector is changing rapidly that there will be greater challenge in the near future. Therefore, it is expected that they will face these challenges more effectively and become one of the vibrant banking sectors among the world competitors.

\section{References}

[1] Mishra, U. S., at al. (2011). CRM in banks: a comparative study of public and private sectors in India. European Journal of Social Sciences, Vol. 24, No. 2, pp. 265-277.

[2] Chang, H. H. (2007). Critical factors and benefits in the implementation of customer relationship management. Total Quality Management Vol. 18, No. 5, pp. 483-508.

[3] Aranata, M.(2006), "CRM Resurgence in Asia: Which Banks Lead the Change?", Financial Insights. 


\section{International Journal of Science and Research (IJSR) \\ ISSN (Online): 2319-7064}

Index Copernicus Value (2013): 6.14 | Impact Factor (2015): 6.391

[4] De Felice, A \& Britt ,P.(2005) "Banking on Big Green", Medford: Customer Relationship Management" Vol $9: 11$, p.34

[5] Jackson, D.(2002), "CRM in financial services", A service excellence white paper, p.10.

[6] Payne, A (2006),"Handbook of CRM: Achieving excellence in customer management", Butterworth Heinemann, Great Britain.

[7] The Analyst - Oct. 2015

[8] Human Capital- Edition-Oct, 2007, Indian Management-Vol.45, oct-07'.

[9] Business India- July,2007 \& Fortune India, July, 07

[10] Marketing Master Mind July \& Aug, 2007.

[11] htpp://fhari.com/mag-news.

[12] htpp://pcru.uu.se/pdf. 